\title{
India's Relations with France and UK in the Indo-Pacific
}

\author{
Rishi Athreya ${ }^{1}$
}

\begin{abstract}
India's maritime domain extends to the Indo-Pacific defined as stretching from the Indian Ocean to the Western Pacific. Many major powers including USA, China and Russia are active in the region. Other NATO middle powers like France and UK too are involved in the IndoPacific. India has maritime diplomacy with these two countries. India has long followed a foreign policy of strategic autonomy. There is a joint military doctrine as also doctrines and strategies by individual forces. France has several policy documents addressing the IndoPacific. It has a direct presence in the region, both in the Indian Ocean and Pacific. The UK too has policy documents. There is scope for India to be a net security collaborator for both countries in their Indo-Pacific operations. Other Commonwealth countries especially Australia also has an important role. The Northern and Southern Hemisphere Quads could move towards a Pacific Group of Seven.
\end{abstract}

Key words: Indo-Pacific, France, UK, Maritime, Commonwealth, Quad, Persian Gulf, South China Sea, Pacific

\section{Indo Pacific Domain}

The Western Pacific and Indian Ocean Region are categorised as the Indo-Pacific. Different countries have varied strategic frontiers and conceptualisation of the 'Indo-Pacific'. India considers the Indo-Pacific as ranging "from the shores of Africa to the shores of the Americas" (Government of India, 2018). This was backed at the East Asia Summit 2019 where the Indian Prime Minister declared the Indo-Pacific Oceans Initiative (Government of India, 2019). The Indo-Pacific is the current template for scrutiny of Indian security and foreign policy (Scott, 2019). Since several crucial SLOCs and ISL pass through the Indo-Pacific. The Indian Navy considers this India's natural habitat and maritime domain. India's maritime domain extends

\footnotetext{
${ }^{1}$ Rishi Athreya is a Research Associate, Asia Centre Bangalore. This paper was presented by the author during the webinar on Emerging India from Maritime Perspective to commemorate National Maritime Day on 05 April 2021. The Event was co-hosted by EJSSS along with UGC Centre for Maritime Studies, Pondicherry University.
} 
across the Indian Ocean right until the Western and South Pacific Seas (Indian Navy, 2016, pp. 31-33) (Parmar, 2014, pp. 49-63). The Indian Navy and Coast Guard carry out patrolling within India's Exclusive Economic Zone (Vasan, 2018). The Indian Navy, however, goes even beyond these limits to patrol a larger area.

Vice Admiral Pradeep Chauhan gives a comprehensive list of India's Maritime Neighbourhood. These are categorised as Immediate, Proximate, Extended, and Strategic neighbourhood. France is part of the Extended and UK part of the Strategic neighbourhood (Chauhan, 2020). While military diplomacy has hitherto been primarily maritime, there is also involvement of air power. This paper intends to study the interaction of India with both France and UK, linking maritime and air power.

\section{India's Military Foreign Policy}

India pursues a Realist approach to Foreign policy (Ranganathan, 2020). Indian Foreign Policy has the concept of Strategic Autonomy (Khilnani, et al., 2012). Experts see this position is seen as a natural continuation of the erstwhile Non-Alignment (Ranganathan, 2020). However, even this position is seen as having a Realist slant (Brewster D. , 2016, p. 5).

Military Doctrines: The latest Joint Doctrine of the Armed Forces was released in 2017 (Headquarters Integrated Defence Staff, 2017). The latest version of the Indian Maritime Doctrine was released in 2016 (Indian Navy, 2015). In the same year, a Maritime Strategy Paper was also released (Indian Navy, 2016).

These provide the conceptual provide a for India's defence policy and strategy, including Military Diplomacy. The 2016 Indian Maritime Doctrine talks of Anarchy. These could be seen as Realist positions.

The Indian Air Force released a doctrine in 2012 (Indian Air Force, 2012). It mentions the vision of the IAF as:

To acquire strategic reach and capabilities across the spectrum of conflict that serve the ends of military diplomacy, nation building and enable force projection within India's strategic area of influence (Indian Air Force, 2012, p. 1).

Defence Diplomacy: Diplomacy and Deterrence are often seen as being intertwined. International defence cooperation/diplomacy is seen as part of national security discourse. 
There is an emerging relationship between defence and political power (Headquarters Integrated Defence Staff, 2017, pp. 22,60). Each of the three forces has a role in Defence Diplomacy. India has in the past few years embarked on a policy of Maritime or Naval Diplomacy. Maritime Diplomacy is a subset of military diplomacy.

The basic aim of India's defence diplomacy is to promote goodwill towards India overseas (Headquarters Integrated Defence Staff, 2017, pp. 21-22), (Jaishankar, 2016). The two main objectives are increasing cooperation and signalling intent to rivals (Athreya R. , 2020). The larger purpose of the navy's diplomatic role is to favourably shape the maritime environment in the furtherance of national interests, in consonance with the foreign policy and national security objectives (Indian Navy, 2015, p. 151). As part of Maritime Diplomacy India has adopted visions of Security and Growth for all in the Region (SAGAR) and Indo-Pacific Oceans Initiative (IPOI) (Athreya R. , 2020b). In the area of Maritime Domain Awareness (MDA) India has created the Information Fusion Centre for the Indian Ocean Region (IFCIOR) in 2018. This too is expected to promote objectives of SAGAR (Indian Navy, 2018). To better implement Defence Diplomacy, India is developing Naval and Air Power particularly in the Andaman Islands (Upadhyaya, 2018, p. 108) (Brewster D. , 2018). India has Military Logistic Agreements with several friendly countries (Thomas, 2019).

This paper shall primarily on maritime diplomacy of India with France and UK. A concern of some scholars has been that India is not effectively engaging in military diplomacy (Malik, 2018 , pp. 181-183). Overall, there is a dearth of scholarly writing on International Defence Diplomacy (Ashraf, 2020).

\section{France}

France is the only NATO country that continues to have a permanent presence in the IndoPacific including the Indian Ocean. This is due to overseas territories in the Indian and Pacific Oceans.

Policy Documents: The French Government has released several documents to enunciate policy on the Indo-Pacific. These are both from the ministries for defence and foreign affairs.

The Defence and National Security Strategic Review of 2017 mentions that France has permanent deployments in overseas territories in the Indian and Pacific Oceans. These areas and their stability is hence of importance to France (French Republic, 2017, p. Para 59). This document considers China a rising power that can challenge the United States (p. Para 118). China's assertion in the South China Sea is seen as significant (p. Para 57). 
A document of the Ministry of Defence titled France and Security in the Indo-Pacific outlines it's policies in the region (Ministere Des Armees, 2019). It lists India as a partner and whose defence capabilities it was upgrading (p. 16). There is a document titled France's Defence Strategy in the Indo-Pacific (Ministere Des Armees, 2019a). This document mentions that US, China, Japan, India, and Australia have adopted maritime strategies. It mentions Australia, India, Japan, and Australia as major defence partners (p. 17). This is significant for India given that India and Australia are members of the Northern Quad along with Japan and USA. The document French Strategy in the Indo-Pacific also mentions India as an important partner (Ministry of Europe and Foreign Affairs, 2019b, p. 16). Thus, as can be seen France has taken the Indo-Pacific very seriously. India too is given importance. An important aspect of the French approach is that there is mention of combined navy and air force exercises. India is specifically cited as holding joint exercises (Ministere Des Armees, 2019, p. 8).

Overseas Territories: The presence of France in the Indian Ocean is due to Reunion Island. New Caledonia, and French Polynesia make France a Pacific power. Given that these territories elect representatives to the National Assembly and Senate and have devolved government France claims these are democratic and not colonial (Scott D. , 2019a, p. 81). In both regions support respectively of India and Australia become important (Grare, 2020). A major concern for France is the tendency for overseas territories to seek independence, especially in Polynesia (Grare, 2020) (Scott D. , 2019a, p. 84). Even were these territories to become independent they would still need security guarantee. This can best be provided by the said regional middle powers. Thus, it makes sense for France to maintain good ties with both countries.

Southern Hemisphere Quad: There is a Pacific Quad or Quadrilateral Defence Coordination Group of nations where in France, Australia, New Zealand, and USA are members (Ministere Des Armees, 2019, p. 10). Australia and USA are members the Northern Hemisphere Quad along with Japan and India. In 2021 there was the first joint declaration of the four nations (Ministry of External Affairs, 2021)

The term Pacific is misleading since both Quads are in this region. Hence this paper shall refer to these are Northern and Southern Quad respectively to reflect the majority membership. France's Pacific territories are being counted in the southern hemisphere.

Trilateral: As aforementioned France has mentioned several partners in the Indo-Pacific. One method of engagement has been trilaterals (Grare, 2020). There are suggestions for an India- 
France-Australia trilateral. It is hoped that this will facilitate building of a coalition to counter China (Pant \& Krishna, 2020).

At a recent workshop organised by the Observer Research Foundation areas of commonality identified included a rules based order and countering China (Observer Research Foundation, 2021). The first foreign secretary level trilateral dialogue was held in Sept 2020 (Ministry of External Affairs, 2020a).

This confirmed cooperation in the Indo-Pacific including in IORA, IOC etc. Some scholars see it as a landmark in enhancing cooperation (Pandey, 2020).

Role in the Middle East: France has a presence in the Middle East. There are close ties between France and UAE. These are common policies on the Middle East and South Asia. An India-France-UAE trilateral will be beneficial in a geopolitical and geoeconomics sphere (Taneja, 2021). There are also plans for France to join the UAE and India in joint Naval Exercises (Rajagopalan, 2021). Joint economic cooperation between companies from France and India in sectors like energy, technology, finance etc will also be mutually beneficial (Rajagopalan, 2021).

Most recently the Indian Air Force participated in the UAE lead Ex DESERT FLAG. Six countries; UAE, USA, France, Saudi Arabia, and Bahrain apart from India participated with aerial assets. Jordan, Greece, Qatar, Egypt, and South Korea participated as observer forces (Indian Air Force, 2021).

India is also seen as a possible mediator between Iran and France (Athreya R. , 2020). This is of considerable importance, given the strained ties between Paris and Tehran due to issues relevant to the Joint Comprehensive Plan of Action (Behal, 2018) (Rajagopalan, 2021).

Agreements: India and France have close political, economic, and military ties (Embassy of India, Paris, 2020). There is cooperation in the Indian Ocean region. The two countries have identified France as a State of the Indian Ocean rim, given its overseas territories of La Réunion, Mayotte and French Southern and Antarctic Territories. They agree to cooperate in this domain (Ministry of External Affairs , 2018).

India and France have signed an agreement akin to the LEMOA Agreement with USA (Embassy of India, Paris, 2020). Access to French naval bases would augment India's ability to be a "net provider of security" and protect the ISLs as also its own SLOCs and those of France. 
Given that France has maritime territories in the Pacific Ocean, the Andaman Islands, too, could be a useful base for maritime cooperation (Vasan, 2018). The cooperation has been once again confirmed at a recent strategic dialogue (Ministry of External Affairs, 2021).

India-France Exercises: Since 2001, the Indian and French Navies have conducted successive annual editions of Exercise VARUNA (Athreya R. , 2020). In May 2019, this exercise was held off the Goa coast and in a second phase at Djibouti (Indian Navy, 2019). A plan is for all four Northern Quad countries to join France for the Ex PEROUSE in April 2021 (Rajagopalan, 2021). The latest Ex MALABAR has consolidate the Northern Quad (Athreya R. , 2020b). It is seen as projecting France's influence and maritime power (Scott D. , 2019a, p. 88).

The Indian and French Air Forces hold the joint Ex GARUDA. The sixth edition was held in France from 1st to 12th July 2019 at Mont-de-Marsan Airbase 118 (French Embassy in New Delhi, 2019). Ex DESERT KNIGHT-21 was held between the two Air Forces in Jodhpur from 20-24 January 2021 (French Embassy in Delhi, 2021).

Defence Supplies: France is a major defence supplier to India and has sold the Rafale Dassault Aircraft to India (Rajagopalan, 2021). These arms sales by France to India can be seen as part of a larger strategy of increasing French influence in the Indo-Pacific. Given India's geographic location and political and military importance it is a reliable ally for France especially for the Indian Ocean territories (Desbonnets, 2020). Some scholars believe that France was a major supplier even during the Cold War and had a role in balancing the Soviet Union. This is reflected in continued cooperation (Pollock, 2020).

Maritime Domain Awareness: France was also the first country to send a liaison officer to the Information Fusion Centre for the Indian Ocean Region (IFC- IOR) (Pajon, 2020, p. 170). This is hoped to increase cooperation in military and constabulary roles (French Embassy in India, 2020).

Benign Domains: There is a view that France and India can cooperate in COVAX and ACT of the WHO (World Health Organisation, 2020) to increase access for Middle and Lower Income Countries to the Covid Vaccine. Further, there can be cooperation in the International Solar Alliance and on environmental issues (Pant \& Krishna, 2020). There is also scope for benign cooperation of navies on issues of Humanitarian and Disaster Relief, climate change etc (Pajon, 2020, p. 167). 


\section{United Kingdom}

From independence in 1947 up until 1964, Indian naval ships participated in the annual joint exercise (JET) at Trincomalee with the British Far East Fleet and other Commonwealth navies, including those of Australia, New Zealand, Pakistan, Sri Lanka, and Malaysia (Upadhyaya, 2018, p. 128) . During the 1962 Indo-China war the UK was not of much help to India.

This turned India towards the then USSR (Upadhyaya, 2018, pp. 77-78). Further given the withdrawal of the Royal Navy from east of the Suez Canal their involvement in the Indian Ocean Region reduced substantially (Upadhyaya, 2018, p. 220).

Policy Documents: The UK periodically releases policy documents to enunciate defence and foreign policy. The latest major document is the Integrated Review of Security, Defence, Development, and Foreign Policy (HM Government, 2021). This supersedes the erstwhile SDSR. There is a mention of Indo-Pacific tilt. On security intensifying geopolitical competition is mentioned. Also stated is the need for freedom of navigation for trade going through multiple choke points (p. 66).

South China Sea and Strait of Hormuz are specifically mentioned (p. 92). The importance of middle powers especially in the Indo-Pacific is highlighted (p. 27). There is a mention of the need for defence and humanitarian relations with India (pp. 62,67).

There is also the UK Maritime Doctrine (Development Concepts and Doctrine Centre, 2017). This mentions the Strait of Hormuz as an important choke point (p. 14). This documents considers naval diplomacy important (p. 22). This can be competitive or collaborative (p. 53).

East of Suez: Some scholars believe that since 2010 there has been a move for the UK to increase engagement East of Suez (Rogers, 2020). The counterview is that the UK never left but merely cutback (Stansfield \& Kelly, 2013). Speaking at the Manama Dialogue of the International Institute of Strategic Studies in December 2016, the then Foreign Secretary Boris Johnson said that disengagement with the East of Suez was a mistake. He indicated a desire of the UK to increase involvement in the Middle East (Johnson, 2016). There is however a view that given the Eurocentric view of the UK it is more likely to concentrate on the Western Indo-Pacific, rather than the South China Sea (Rogers, 2020).

Middle East: The Royal Navy under the banner of Op KIPION has had a presence in the Persian Gulf since the days of the Iran-Iraq War in the 1980s. An important role is a patrol of maintain security of shipping lanes. UK Maritime Component Command (UKMCC) is the command element of Op KIPION. The UKMCC exercises command and control of the various 
Royal Navy and Royal Fleet Auxiliary ships in the region (Royal Navy , 2021). This is of relevance since India has the GULFDEP patrol in the Middle East (Athreya R. , 2020).

In pursuance of Maritime Diplomacy, the UK participated in Ex KHUNJAR HADD - Arabic for sharp dagger- hosted by the Royal Navy of Oman. The US Navy and Coast Guard, French Air Force, and Royal Air Force of Oman also participated in the exercises. This exercise while promoting joint operations also ensures security of shipping (Royal Navy, 2021).

This exercise is noteworthy since it combines maritime and air power. Further, it shows the joint working of UK and France in the Persian Gulf. The US too supports these efforts. India too has the Ex NASEEM-AL-BAHR with Oman (Athreya R. , 2020).

The UK has created new infrastructure in the region. There is a new United Kingdom Naval Support Facility at Mina Salman port in Bahrain. (Royal Navy , 2018). The UK further has the British Logistics Support Base at Duqm in Oman (Ministry of Defence, 2019). This has been further upgraded specially to maintain FoN in the Strait of Hormuz (Ministry of Defence, 2020). This is relevant since India too has access to the Duqm port (Athreya R. , 2020).

South China Sea: In August 2018, the amphibious assault ship HMS Albion traversed the Paracel archipelago while going from Tokyo to Hanoi. This can be seen as negating China's claims on the South China Sea (Rogers, 2020). This shows the UK's willingness for taking risks to uphold the maritime rights of small and medium countries. Further it is an assertion of interest of the UK in a global role (Hemmings, 2019). An important aspect of the UK is Five Powers Defence Agreement (FPDA) along with Australia, Malaysia, New Zealand, and Singapore (Hemmings \& Rogers, 2020, p. 122). This grouping recently celebrated its fiftieth anniversary and issued a joint declaration supporting humanitarian activities (Mindef Singapore, 2020). The UK is keen to enhance cooperation in the maritime sphere (HM Government, 2021, p. 67). British scholars hold that the UK has bases in Singapore and Brunei that qualify it to be an Indo-Pacific power. There is a view that the Pitcairn Islands qualify the UK as a resident power in the Pacific (Hemmings \& Rogers, 2020, p. 123). The British High Commissioner to the New Zealand is the Governor of these territories. Further, the islands depend heavily on New Zealand. Thus, while the UK may have a nominal presence in the region, it is effectively administered from Wellington.

The UK has a defence partnership with Japan. There are plans to deploy UK Carrier Strike Group headed by HMS Queen Elizabeth of the Indo-Pacific in mid-2021 (Ministry of Defence 
, 2021). It is hoped to project UK maritime power and signal cooperation with allies (HM Government, 2021, p. 5).

UK-India Agreements: Notwithstanding the supposed Comprehensive Strategic Partnership there has been little interactions between the militaries of the two countries (Ladwig, 2021) (Roy-Chaudhury, 2020). One major issue is the lack of defence procurement from the UK. This is since there is no government-to-government negotiation of deals, but only commercial transactions (Dave, 2020), (Roy-Chaudhury, 2020).

India-UK Exercises: Ex KONKAN is the generic name of a series of exercise between the Indian Navy and the British Royal Navy, which has, since its inception in 2004, grown in complexity and scale (Indian Navy, 2019). Both navies have, over the years, also undertaken bilateral activities such as training exchanges and technical cooperation. Ex KONKAN is usually held off Goa.

The 2019 edition, however, was held in the English Channel (Royal Navy, 2019). The Indian Air Force and Royal Air Force have held the joint Ex INDRADHANUSH since 2013 (Royal Air Force, 2020). The fifth edition was held in Air Force Station Hindon from 24-29 February 2020 (Indian Air Force, 2020).

Training: An important part of India's defence relations with UK is training of officers at each other's academies including at one star level (Roy-Chaudhury, 2020).

\section{Emerging Issues}

Based on the detailed analysis of India's maritime relations with France and UK certain issues emerge:

Geography: The major difference between France and UK is geography. While France has an actual physical presence both in the Indian Ocean and South Pacific, the UK has no such direct presence. The onetime UK territories are now independent dominions. This includes members of the FPDA. This is a result of the Balfour Declaration (Imperial Conference, 1926) and the Statue of Westminster of 1931 (Commonwealth Secretariat, 2020). Even the Pitcairn Islands is dependent on New Zealand. Thus, while the domain of French involvement goes right until the Australian east coast, the UK is not really concerned of areas beyond the Persian Gulf. There is of course the issue of independence for French Indian Ocean and Pacific territories. 
Middle Power Cooperation: As can be seen the UK and France are actively cooperating in the Persian Gulf. France is seen as a Middle Power (Scott D. , 2019, p. 81). Notwithstanding direct presence through overseas territories, for France cooperation of regional middle powers as net security coordinators becomes important. India and Australia are ideally suited to fit this role. This can be akin to the India's relations with Mauritius and Seychelles (Athreya R. , 2020, pp. 42-43). Although Mauritius was a dominion until 1992, India has been active in that country since 1978.

France and Australia have close strategic diplomatic, military, and economic cooperation (DFAT, 2018). France can be said to have a policy of Strategic Autonomy. It thus may not want to be part of an alliance that is led by the US against China (Pajon, 2020, p. 174).

The UK too is keen to avoid Cold War style alliances and is in favour of cooperating with Middle Powers (HM Government, 2021, p. 27). Dr Malcolm Chalmers believes that the UK sees itself as a Middle Power (Chalmers, 2021, p. 3). To the extent there is any interest for UK east of India it is mainly in cooperation with Australia, New Zealand, and USA. There could possibly be similar cooperation with India.

Given India's close ties with Australia there are suggestions to build on the Commonwealth connection and for this to be extended to the UK (Athreya R. , 2020b, p. 74). There is also support for India and Australia from the UK (Hemmings, 2019). All FPDA countries are Commonwealth states. The UK too is keen to build on Commonwealth ties (HM Government, 2021, p. 61).

Further Joint Multinational Exercises: India has maritime cooperation with France. There are suggestions for joint cooperation with UAE. The UK and USA are also active in this region. There may also be scope for such cooperation with Oman too. Future joint exercises could include India. The South China Sea is an important theatre of action for both the French Navy and the UK Royal Navy. France has a direct interest since it has to transit that area to reach its Pacific territories. Future editions of Ex MALABAR could also include France and UK.

Indian Air-Maritime Joint Operations: The recent Ex KHUNJAR HADD with France in the Middle East show the need for joint operations between the Indian Navy and Indian Air Force. The role of Air Power in supporting maritime diplomacy remains a further area of research.

At a governance level the role of the Integrated Defence Staff also becomes important. This is reflected in the Joint Doctrine where it is mentioned that Long-term and annual objectives, for international cooperation/defence diplomacy, must be drawn up in close consultation with 
Heads of Missions, Ministry of External Affairs and Ministry of Defence (Headquarters Integrated Defence Staff, 2017, pp. 21-22).

Quads: There has been much speculation about expanding the Northern Quad. Due to Covid, there are suggestions to include New Zealand, South Korea, and Vietnam (DFAT, 2020). Given that Ex PEROUSE already includes the other three Northern Quad members, it is natural for India to join this exercise.

MDA: Maritime Domain Awareness will continue to be an important issue. France has clearly been able to create ties with India.

Infrastructure: India could cooperate with both the UK and France in building infrastructure in the Middle East. The Duqm port is a common interest to both India and the UK.

Procurement: Technology transfer is an important element of defence cooperation. This is particularly relevant to the Make in India agenda. France is relating to India at a government to government level and having effective cooperation.

\section{Multilateral Bodies}

There are multilateral bodies present in the region. India along with France and UK is active in these too.

IORA: The Indian Ocean Rim Association (IORA, 2021) could be said to be the closet to a multilateral body for Indian's Maritime Neighbourhood (Khurana G. , 2018). France was admitted as a member based on the Indian Ocean territory of Reunion Island (France Diplomacy, 2020).

IONS: The Indian Ocean Naval Symposium (IONS), an Indian initiative established in 2008 (Royal Australian Navy, 2021). It brings together 35 navies and coast-guards seeks to increase maritime cooperation among navies of the littoral countries of the Indian Ocean Region (Padmaja, 2017).

France was a founding member of this organisation (Scott D. , 2019a, p. 85). The UK by virtue of British Overseas territory of Diego Garcia is also a member. There was the Indian Ocean Naval Symposium Multilateral Maritime Search and Rescue Exercise styled Ex IMMSAREX held on the Bangladesh coast from 25-29 November 2017. China and Indonesia also participated in this exercise (Indian Navy, 2017).

China is among the observer countries (Royal Australian Navy, 2021). 
Indian Ocean Commission: The Indian Ocean Commission (IOC) is an international organisation established in 1982 (Indian Ocean Commission, 2021). Its member states are the Indian Ocean islands States of Comoros, Madagascar, Mauritius, Reunion, and Seychelles. The goals of the IOC are mainly developmental, with little political activity. Of the member states, two are maritime allies of India. France, too, is part of this body. There are suggestions for India to be granted observer status (Behal, 2018).

European Union: The anti-piracy patrol Op ATALANTA is held by the EU European Union Naval Force (EU NAVFOR) in and off the Gulf of Aden. The primary aim is Constabulary especially counter-piracy (EU Naval Force-Somalia, 2020). This a Combined Maritime Force in the region headed by a US Navy Three-Star Admiral. France and UK are naturally part of this group. Interestingly from India's point of view Pakistan is also a member (Combined Maritime Forces, 2020). There has in the past been cooperation with India, China, and Russia in the region.

NATO India Relations: An expert group was appointed by the Secretary General to assess ways to strengthen the political work of NATO (NATO Expert Group, 2020). This sees China as a threat (p. 17). There are recommendations to increase cooperation with pacific partners including Australia, Japan, New Zealand, and Republic of Korea. Possible partnership with India is also mentioned (p. 60). There are earlier suggestions for partnership with India including in the maritime sphere. This is seen as building on existing ties with NATO members (Hacioglu, 2020).

Commonwealth: The Commonwealth Secretariat is especially important for maritime affairs and economic and security objectives. There are documents like Commonwealth Blue Charter (Commonwealth Secretariat, 2018), and Commonwealth Connectivity Agenda (Commonwealth Secretariat, 2018a) that are seen as of relevance (Dave, 2020). India along with UK and Australia can provide technical expertise in these domains. There is also scope for other Commonwealth Indo-Pacific and South China Sea littoral states to be involved.

\section{Conclusion}

This article is intended to examine the nature of interaction in terms of maritime diplomacy of India with France and UK in the Indo-Pacific. The major policy documents of all three countries have been scrutinised. 
A finding of this paper is that Air Forces are being deployed along with Navies. Thus, it has touched upon the role of the Indian Air Force alongside the Indian Navy in maritime diplomacy. The Doctrines of both forces as also joint doctrine of the Indian Armed Forces have been quoted. In future both maritime and air power diplomacy would have to operate jointly.

As can be seen there is middle power cooperation of India with France and UK in the IndoPacific. France is a resident power in the Indian Ocean. It is also active in the Persian Gulf. It too would need to cooperate with India for the security of its Indian Ocean territories.

The UK has a direct presence only in the Persian Gulf. Here too it has to cooperate with France, and USA. It would be a natural progression for India to also be a regional net security partner.

In the South China Sea and Pacific Ocean there are suggestions for a trilateral with India Australia and France. Given the geographic location Australia would be a natural partner for France. Notwithstanding the specific governance structures for French Overseas Territories the geographic proximity makes the role of India and Australia vital as net security collaborators and providers. Given the common thread of Strategic Autonomy these countries can come together.

In the South China Sea and Pacific Ocean, the UK will only be able to cooperate with partners. Commonwealth connections are effectively the UK's best raison d'être to be present the South China Sea, Indian Ocean, and Pacific. This includes the FPDA countries. Further, New Zealand continues to secure the Pitcairn Islands.

This article has highlighted both Quads together. Given that US and Australia are part of the both the Northern and Southern Quad there may be a case for a Pacific Group in the region. Were UK to also join this group, it could become the P 7.

All three countries namely India, France and UK have their own governance and political issues to address. India would need to integrate maritime and air power. France would need to move towards effective governance arrangements with overseas territories. The UK would have to associate on an equal footing with dominions including Australia and even New Zealand. The UK would also have to build ties with India, and other Commonwealth countries. In some cases, these others may even take the lead.

The role of India has been discussed in this paper. An outcome of this research is that Australia too has an important part in the Indo Pacific and with the Commonwealth. Since the pivot of the world is considered as shifting to the Indo Pacific these two middle powers would be key to regional and global security for decades to come. Given that New Zealand is a 
Commonwealth country and also part of the Southern Quad its role needs to be scrutinised. India-New Zealand relations can be a further topic of study. Knowing the decline of UK, were such a group to be formed it would need to be led by Australia and India in their respective geographic regions. Ninety years after the signing of the Statute of Westminster and ninety five years after the Balfour Declaration the Commonwealth has come a full circle.

Technological factors too will influence cooperation as part of maritime diplomacy. This includes MDA, defence technology and infrastructure. Here too France has been more effective than the UK. Continued cooperation of India with both countries in these domains will be needed.

International Organisations in the region will play an important role. Given that India and France are important players they would have to take the lead. The UK and Australia too have an important part in these groupings. There may even be scope to negotiate with China since it too is an observer in IONS.

Constabulary role of maritime forces is also an important part of cooperation of India with the EU including France and UK. The benign role of navies also becomes relevant.

This article has shown the interface of India with two major NATO middle powers and P5 members besides the USA in the Indo Pacific. Going forward, France and UK will be important allies for India.

\section{References}

Ashraf, A. (2020). Deterrence and Diplomacy . In F. A. (Ed.), Deterrence. Advanced Sciences and Technologies for Security Application.

Athreya, R. (2020). Maritime Diplomacy: Furthering India's Interests in the IOR. In P. Chauhan, R. S. Vasan, R. Athreya, \& R. V. P. Chauhan (Ed.), Securing India's Maritime Neighbourhood: Challenges and Opportunities (pp. 45-64). National Maritime Foundation.

Athreya, R. (2020a, June 28). Galwan Incident: Larger Implications for Sino-India Relations. Retrieved from Asia Centre Bangalore: https://asiacentrebangalore.org/2020/06/29/galwanincident-larger-implications-for-sino-india-relations/

Athreya, R. (2020b, Oct Dec). Ex MALABAR 2020: Implications for India-Australia Ties. Defence and Diplomacy, 10(1), 61-76.

Behal, A. (2018, Aug 16). India and France: Towards a new maritime partnership. Retrieved from Observer Research Foundation: https://www.orfonline.org/expert-speak/43376-indiaand-france-towards-a-new-maritime-partnership/ 
Brewster, D. (2016). Australia, India and the United States: The Challenges of forging new alignments in the Indo-Pacific. University of Sydney . United States Studies Centre .

Brewster, D. (2018). India and China at Sea: Competition for Naval Dominance in the Indian Ocean. SADF.

Chauhan, P. (2020). Foreword. In P. Chauhan, R. S. Vasan, \& R. Athreya, Securing India's Maritime Neighbourhood: Challenges and Opportunities. Vij Books.

Chhibber, A. (2017). China's belt and road initiative and India's options: Cooperative competition. Journal of Infrastructure, Policy and Development, 1(2).

Combined Maritime Forces. (2020). Combined Maritime Forces. Retrieved from CMF: https://combinedmaritimeforces.com/

Commonwealth Secretariat . (2018). The Connectivity Agenda. Retrieved from Commonwealth Secretariat: https://thecommonwealth.org/connectivity-agenda

Commonwealth Secretariat. (2018). The Commonwealth Blue Charter. Commonwealth Secretariat. Retrieved from https://bluecharter.thecommonwealth.org/

Dave, A. (2020, May 5). Integrated Review: The UK's Approach to India. Retrieved from Royal United Services Institution : https://rusi.org/commentary/integrated-review-uksapproach-india

Desbonnets, M. (2020, May 20). France and Make in India and the Indo-Pacific Connect. Retrieved from National Maritime Foundation : https://maritimeindia.org/france-make-inindia-and-the-indo-pacific-connect/

Development Concepts and Doctrine Centre. (2017). UK Maritime Power. Ministry of Defence.

DFAT. (2020, June 5). Joint Statement on a Comprehensive Strategic Partnership between Republic of India and Australia. Retrieved from Department of Foreign Affairs and Trade: https://www.dfat.gov.au/geo/india/Pages/joint-statement-comprehensive-strategic-

partnership-between-republic-india-and-australia

Embassy of India, Paris. (2020). Brief on India-France Bilateral Relations. Retrieved from Embassy of India, Paris: https://www.eoiparis.gov.in/page/bilateral-brief/

Embassy of India, Paris. (2020). Brief on India-France Bilateral Relations. Retrieved from Embassy of India : https://www.eoiparis.gov.in/page/bilateral-brief/

EU Naval Force-Somalia. (2020). Op ATALANTA. Retrieved from EU Naval Force-Somalia: https://eunavfor.eu/mission/

France Diplomacy. (2020, Dec 17). Indian Ocean - France's accession to the Indian Ocean Rim Association. Retrieved from France Diplomacy: https://www.diplomatie.gouv.fr/en/country-files/africa/france-in-the-south-west-indianocean/article/indian-ocean-france-s-accession-to-the-indian-ocean-rim-association-17-12-20 
French Embassy in Delhi. (2021, Feb 20). French and India Air Forces hold joint exercise in Jodhpur. Retrieved from French Embassy in New Delhi: https://in.ambafrance.org/Frenchand-India-Air-Forces-hold-joint-exercises-in-Jodphur

French Embassy in India. (2020, Sept 11). A French Liaison Officer at the Indian Navy's Information Fusion Center. French Embassy in India. Retrieved from https://www.youtube.com/watch?v=TkYhRCKjpGk

French Embassy in New Delhi. (2019, July 12). Indo-French Air Exercise "Garuda VI". Retrieved from French Embassy in India: https://in.ambafrance.org/Indo-French-Air-ExerciseGaruda-VI

French Republic. (2017). Defence and National Security Strategic Review. French Republic .

Government of India. (2018, June 1). Prime Minister's Keynote Address at Shangri La Dialogue. Retrieved from Ministry of External Affairs: https://www.mea.gov.in/SpeechesStatements.htm?dtl/29943/Prime+Ministers+Keynote+Address+at+Shangri+La+Dialogue+Ju ne $+01+2018$

Government of India. (2019, 11 4). Transcript of Media Briefing by Secretary (East) during PM's visit to Thailand. Retrieved from Ministry of External Affairs : https://www.mea.gov.in/media-

briefings.htm?dt1/32007/Transcript_of_Media_Briefing_by_Secretary_East_during_PMs_vis it_to_Thailand_November_04_2019

Grare, F. (2020, Oct 21). France, the Other Indo-Pacific Power. Retrieved from Carnegie Endowment: https://carnegieendowment.org/2020/10/21/france-other-indo-pacific-powerpub-83000

Hacioglu, A. U. (2020). The case for NATO's global partnership with India. NDC Policy Brief , NATO Defense College, Research Division.

Headquarters Integrated Defence Staff. (2017). Joint Doctrine of the Indian Armed Forces. HQ IDS.

Hemmings, J. (2019, Feb 6). Charting Britain's Moves in the South China Sea. Retrieved from RUSI: https://rusi.org/commentary/charting-britain\%E2\%80\%99s-moves-south-china-sea

Hemmings, J., \& Rogers, J. (2020). Britian and the Quadrilateral. Journal of Indo Pacific Affairs, 3(5), 118-130.

HM Government. (2021). Global Britian in a competitive age. HMG.

Indian Air Force. (2012). Basic Doctrine of the Indian Air Force. Indian Air Force.

Indian Air Force. (2020, Feb 26). Joint IAF - RAF EX Indradhanush - V 2020. Retrieved from Ministry of Defence: https://pib.gov.in/newsite/PrintRelease.aspx?relid=199574

Indian Air Force. (2021, March 30). Press Release Ex DESERT FLAG. Retrieved from Indian Air Force: https://indianairforce.nic.in/content/press-release-exercise-desert-flag-vi

Indian Navy. (2007). Freedom to use the Seas. Indian Navy.

Indian Navy. (2009). Indian Maritime Doctrine. Indian Navy. 
Indian Navy. (2015). Indian Maritime Doctrine. Indian Navy.

Indian Navy. (2016). Ensuring Secure Seas. New Delhi: Indian Navy.

Indian Navy. (2017). IMMSAREX. Retrieved from Indian Navy: https://www.indiannavy.nic.in/content/immsarex

Indian Navy. (2018). Information Fusion Centre- Indian Ocean Region . Retrieved from Indian Navy: https://www.indiannavy.nic.in/ifc-ior/about-us.html

Indian Navy. (2019, Dec 1). Exercise Konkan 16. Retrieved from Indian Navy : https://www.indiannavy.nic.in/content/exercise-konkan-16

Indian Navy. (2019). Indian and French Navies Conduct Varuna 19.1 Bilateral Exercise Off Goa Coast. Retrieved from Indian Navy: https://www.indiannavy.nic.in/node/22661

Indian Ocean Commission. (2021). Retrieved from https://www.commissionoceanindien.org/

IORA. (2021, April 1). IORA. Retrieved from IORA: https://www.iora.int/en

Jaishankar, D. (2016). India's Military Diplomacy. In S. SIngh, P. Das, S. Singh, \& P. Das (Eds.), Defence Primer: India at 75 (pp. 18-25). Observer Research Foundation.

Johnson, B. (2016). IISS Manama Dialogue Keynote Address. Manama Dialogue . IISS. Retrieved from https://www.iiss.org/events/manama-dialogue/manama-dialogue-2016

Khilnani, S., Kumar, R., Mehta, P. B., Menon, P., Nilekani, N., Raghavan, S., . . Varadarajan, S. (2012). NonAlignment 2.0: A Foreign and Strategic Policy for India in the Twenty First Century. Centre for Policy Research .

Khurana, G. (2018). Multilateral Structures in the Indian Ocean: Review and Way Ahead . Maritime Affairs, 14, 11-23.

Khurana, G. S. (2019). Multilateral Strucutres in the Indian Ocean: Review and Way Ahead. Maritime Affairs, 14(1), 11-23.

Ladwig, W. C. (2021, Jan 8). Are the UK and India Finally Getting Serious About Each Other? Retrieved from RUSI: https://rusi.org/commentary/are-uk-and-india-finally-getting-seriousabout-each-other

Malik, V. (2018 ). India's Military Conflicts and Diplomacy. Harper Collins .

Mindef Singapore. (2020, Nov 27). FPDA Defence Ministers' Joint Statement on Continued Commitment to the FPDA. Retrieved from Mindef Singapore: https://www.mindef.gov.sg/web/portal/mindef/news-and-events/latest-releases/articledetail/2020/November/27nov20_fs

Ministere Des Armees. (2019). France and Security in the Indo-Pacific. Government of France.

Ministere Des Armees. (2019a). France's Defence Strategy in the Indo-Pacific. Ministere Des Armees. 
Ministry of Defence . (2021, Feb 3). UK commits to deeper defence and security cooperation with Japan. Retrieved from UK Government: https://www.gov.uk/government/news/ukcommits-to-deeper-defence-and-security-cooperation-with-japan

Ministry of Defence. (2019, Feb 21). UK and Oman sign historic Joint Defence Agreement. Retrieved from UK Government: https://www.gov.uk/government/news/uk-and-oman-signhistoric-joint-defence-agreement

Ministry of Defence. (2020, Sept 12). Defence Secretary announces investment in strategic Omani port. Retrieved from UK Government : https://www.gov.uk/government/news/defencesecretary-announces-investment-in-strategic-omani-port

Ministry of Europe and Foreign Affairs. (2019b). French Strategy in the Indo-Pacific. Ministry of Europe and Foreign Affairs.

Ministry of External Affairs . (2018, March 10). Joint Strategic Vision of India-France Cooperation in the Indian Ocean Region. Retrieved from Ministry of External Affairs: https://www.mea.gov.in/bilateral-

documents.htm?dtl/29598/Joint+Strategic+Vision+of+IndiaFrance+Cooperation+in+the+Indi an+Ocean+Region+New+Delhi+10+March+2018

Ministry of External Affairs. (2020a, Sept 9). 1st Senior Officials' India-France-Australia Trilateral Dialogue. Retrieved from Minsitry of External Affairs: https://www.mea.gov.in/press-

releases.htm?dtl/32950/1st+Senior+Officials+IndiaFranceAustralia+Trilateral+Dialogue

Ministry of External Affairs. (2021, Jan 9). India and France hold Strategic Dialogue. Retrieved from Ministry of External Affairs: https://mea.gov.in/pressreleases.htm?dt1/33376/India_and_France_hold_Strategic_Dialogue

Ministry of External Affairs. (2021, March 12). Quad Leaders' Joint Statement: “The Spirit of the Quad". Retrieved from Government of India: https://www.mea.gov.in/bilateraldocuments.htm?dtl/33620/Quad+Leaders+Joint+Statement+The+Spirit+of+the+Quad

NATO Expert Group. (2020). NATO 2030: united for a new era. NATO.

Observer Research Foundation. (2021, Feb 12). The India-Japan-France trilateral cooperation to tackle the rising Chinese hegemony. Retrieved from Observer Research Foundation: https://www.orfonline.org/research/the-india-japan-france-trilateral-cooperation-to-tacklethe-rising-chinese-hegemony/

Padmaja, G. (2017, Aug 21). India and Mauritius: Cooperating to ensure collective security. Retrieved from National Maritime Foundation : https://maritimeindia.org/india-and-mauritiuscooperating-to-ensure-collective-maritime-security/

Padmaja, G. (2018). Revisiting 'SAGAR' - India's Template for Cooperation in the Indian Ocean Region . National Maritime Foundation .

Pajon, C. (2020, 12). France's Indo- Pacific Strategy. Journal of Indo-Pacific Affairs, 3(5), 165-178. 
Pandey, P. (2020, Oct 2). India-France-Australia: Emerging Trilateral in the Indo-Pacific. Retrieved from Indian Council for World Affairs: https://www.icwa.in/show_content.php?lang=1\&level=3\&ls_id=5369\&lid=3796

Pant, H. V., \& Krishna, M. S. (2020, Dec 19). Lessons from 2020 - Next steps for the FranceIndia partnership. Retrieved from ORF: https://www.orfonline.org/research/lessons-2020next-steps-france-india-partnership/

Parmar, S. (2014). Maritime Security in the Indian Ocean an Indian Perspective. Journal of Defence Studies, 8(1), 49-63.

Pollock, J. (2020, Oct 19). India and France: From Strategic Partners to Strategic Alliance . Retrieved from South Asian Voices: https://southasianvoices.org/india-and-france-fromstrategic-partners-to-a-strategic-alliance/

Raghavan, P. (2019, Spring). India's Interest in the Indo-Pacific. Scholar Warrior, 14-18.

Rajagopalan, R. P. (2021, March 14 ). A Proactive Indian Navy: Upcoming Naval Exercises. Retrieved from Observer Research Foundation : https://www.orfonline.org/research/aproactive-indian-navy-upcoming-naval-exercises/

Rajagopalan, R. P. (2021, March 13). A Proactive Indian Navy: Upcoming Naval Exercises. Retrieved from ORF: https://www.orfonline.org/research/a-proactive-indian-navy-upcomingnaval-exercises/

Ranganathan, C. (2020). India's Regional Alliances in the Indo-Pacific. In P. Chauhan, R. S. Vasan, R. Athreya, \& R. V. P.Chauhan (Ed.), Securing India's Maritime Neighbourhood: Challenges and Opportunities (pp. 31-40). National Maritime Foundation.

Rogers, J. (2020, Dec 15). Britain tilts towards the Indo-Pacific. Retrieved from ASPI The Strategist: https://www.aspistrategist.org.au/britain-tilts-towards-the-indo-pacific/

Royal Air Force. (2020, Feb 24). RAF on Exercise Indradhanush. Retrieved from Royal Air Force : https://www.raf.mod.uk/news/articles/raf-on-exercise-indradhanush/

Royal Australian Navy. (2021). Indian Ocean Naval Symposium. Retrieved from Royal Australian Navy: https://www.navy.gov.au/ions

Royal Navy . (2018, April 6). New Royal Navy Operations Hub opens in Middle East . Retrieved from Ministry of Defence : https://www.royalnavy.mod.uk/news-and-latestactivity/news/2018/april/06/180406-new-royal-navy-operations-hub-opens-in-gulf

Royal Navy . (2021, Jan 1). Op KIPION . Retrieved from Royal Navy: https://www.royalnavy.mod.uk/news-and-latest-activity/operations/red-sea-andgulf/operation-kipion

Royal Navy. (2019, Aug 15). British and Indian Navies Join Forces in Channel. Retrieved from Royal Navy: https://www.royalnavy.mod.uk/news-and-latestactivity/news/2019/august/15/190815-british-and-indian-navies-join-forces-in-channel

Royal Navy. (2021, March 16). Royal Navy Sharpens it's skills in key Gulf Exercise. Retrieved from Ministry of Defence : https://www.royalnavy.mod.uk/news-and-latestactivity/news/2021/march/16/20210316-khunjar-hadd 
Roy-Chaudhury, R. (2020, Feb 5). Boosting India-UK defence and military ties: new thinking and emerging opportunities. Retrieved from IISS: https://www.iiss.org/blogs/analysis/2020/02/sasia-india-uk-defence-and-military-ties

Sarangi, S. (2020). Indo-Pacific Oceans' Initiative (IPOI): India's Indo-Pacific concept translated into action. Retrieved from United Services Institution of India : https://usiofindia.org/publication/cs3-strategic-perspectives/indo-pacific-oceans-initiativeipoi-indias-indo-pacific-concept-translated-into-action/

Scott, D. (2019). India and the Indo-Pacific Discourse. In D. Scott, \& H. Pant (Ed.), New Directions in India's Foreign Policy (pp. 195-214). Cambridge: Cambridge University Press .

Scott, D. (2019a). France's "Indo-Pacific" strategy: regional power projection. Journal of Military and Strategic Studies, 19(4), 76-103.

Stansfield, G., \& Kelly, S. (2013). A Return to East of Suez. Briefing Paper, RUSI.

Taneja, K. (2021, Jan 23). The India and France bonhomie has potential for expansion with the Gulf. Retrieved from ORF: https://www.orfonline.org/expert-speak/india-francebonhomie-potential-expansion-gulf/

Thomas, R. (2019, Nov 26). Military Logistics Agreements: Wind in the Sails for Indian Navy. Retrieved from IDSA: https://idsa.in/idsacomments/military-logistics-agreements-rthomas261119

Upadhyaya, S. (2018). Maritime Security Cooperation in the Indian Ocean Region: Assessment of India's Maritime Strategy to be the Regional "Net Security Provider",. Wollongong: University of Wollongong.

Upadhyaya, S. (2018). Maritime Security Cooperation in the Indian Ocean Region: Assessment of India's Maritime Strategy to be the Regional "Net Security Provider",. University of Wollongong.

Vasan, R. S. (2018). Indian Navy's CAMPING . Retrieved from National Maritime Foundation.

Vasan, R. S. (2018, March 8). The French Connection in the Indian Ocean. Retrieved from Chennai Centre for China Studies: https://www.c3sindia.org/defence-security/the-frenchconnection-in-the-indian-ocean-by-commodore-r-seshadri-vasan-in-retd/

World Health Organisation. (2020, July 24). COVAX. Retrieved from World Health Organisation: https://www.who.int/initiatives/act-accelerator/covax 